This PDF is a selection from an out-of-print volume from the National Bureau of Economic Research

Volume Title: An Appraisal of the 1950 Census Income Data Volume Author/Editor: Conference on Research in Income and Wealth Volume Publisher: Princeton University Press

Volume ISBN: 0-691-04102-4

Volume URL: http://www.nber.org/books/unkn58-2

Publication Date: 1958

Chapter Title: The 1950 Census and the Post-Enumeration Survey

Chapter Author: Leon Pritzker, Alfred Sands

Chapter URL: http://www.nber.org/chapters/c1054

Chapter pages in book: (p. 205 - 240) 


\title{
The 1950 Census and the Post-Enumeration Survey
}

\author{
Leon Pritzker, bureau of the census and \\ CASE INSTITUTE OF TECHNOLOGY
}

Alfred SANDS, bureau of THE Census

\section{Introduction}

This paper will describe the Post-Enumeration Survey of the 1950 Censuses of Population, Housing, and Agriculture. We shall be concerned mainly with what the PES has to say about the accuracy of the 1950 census percentage distributions of the population with respect to income. We shall also strive to make clear the methods and techniques of the PES, as well as its assumptions and limitations.

\section{DEFINITIONS USED}

The PES provides a basis for evaluating both the data and the statistics of the 1950 censuses. By a datum, we mean an edited and coded recording of an individual response to a census inquiry. By a statistic, we mean any result of a tabulating and computing operation carried out on data; a total, a median, or a percentage.

We use the term gross error to refer to errors in data; for example, the failure to list a person on the rolls of the census, the erroneous reporting, recording, or coding of income. We use the term net error to refer to errors in statistics, deviations from "true values."

\section{INTERPRETATION OF RESULTS}

The PES results can be viewed in two ways: first, as estimates of difference between two enumerations of the same population; second, as estimates of error in the original enumeration. In this paper, we shall in most cases take the latter position. The assumptions on which this view is based are set forth in the next section.

Tables 1 and 2 provide some results relating to the income data of the 1950 Census of Population. There were errors in obtaining in-

Note: The PES was the product of many minds. We would have to list at least fifty names if we were explicitly to acknowledge the contributions of others to the production of the results and of the ideas contained in this paper. We choose instead to acknowledge our own responsibility for the errors and omissions of this particular presentation as well as to disclaim any credit for whatever is included of value. 
come data in the PES as well as in the 1950 census. Hence, with regard to the evaluation of data, we take the first position stated above. The PES furnishes estimates of gross difference between the data obtained in two enumerations of the same population, and not of gross error in the 1950 census. Yet we regard the PES as accurate enough to evaluate the net errors of the 1950 census.

\section{QUANTITATIVE ESTIMATES OF ERROR}

At present, only a start has been made by the Bureau of the Census in the development of methods for measuring accuracy. Some of this work has been documented. ${ }^{1}$ Beginning in 1945, we have been experimenting with two methods, the record check and the re-enumerative check. The PES incorporated both. The papers in this volume that compare census data with data of the Survey Research Center, the Bureau of Old-Age and Survivors Insurance, and the Internal Revenue Service are based on information derived from the PES. This paper is concerned with the re-enumerative check of the PES.

\section{THE NATURE OF THE CHECK}

Four or five months after the start of the original census enumeration on April 1, 1950, intensive recanvasses were made of samples of small areas designed to represent the United States. The object was to find people, dwellings, and farms that were missed in the original enumeration. At the same time, and mostly in the same areas, intensive reinterviews were conducted with a sample of the population enumerated in the census in the hope of obtaining information of sufficient accuracy to evaluate that obtained in the original enumeration. The check was designed along the following lines:

1. It was as close to a "maximum intensity" procedure as could be designed. Contrast, for example, the probing-type questions used to obtain income data in the PES with the global-type questions of the census enumeration (see the appendix, Exhibits A-1 and A-2). Roughly twenty times more money was spent per case than in the original enumeration. In the census enumeration, a single individual could answer for all members of a household; in the check, the "best" respondent had to be sought out, even at the expense of repeated calls. The "best" respondent was generally regarded as the person for whom the information was required. Thus, in general, each adult was queried about his own income.

${ }^{1}$ A. Ross Eckler and Leon Pritzker, "Measuring the Accuracy of Enumerative Surveys," paper presented before the 27th Session of the International Statistical Institute, New Delhi, India, December 5, 1951. 


\section{950 CENSUS AND PES}

2. About 250 superior interviewers were obtained, given more training, and provided with closer supervision than was possible for the 130,000 census enumerators.

3. The check provided for case-by-case comparison and, usually, reconciliation. The interviewers, for example, were provided with transcripts of the original income data obtained for 95 out of every 100 persons in the "personal income subsample." They were instructed not to examine these transcripts until they had obtained responses to their questions.

\section{Major Assumptions Underlying the PES}

We have stated our view that the PES results provide estimates of net error in the income statistics of the 1950 census. Four major assumptions are required for this position. Not one of them can be accepted unreservedly, and to the extent that they cannot, they limit the validity of the PES results.

\section{TRUE VALUES EXIST}

This is the assumption that there was a precisely defined true value for the income in 1949 of everyone in the United States. In the light of the definitions and instructions provided in the Enumerator's Reference Manual for the 1950 census, however, there was at least one case in which two income analysts, in possession of "all the facts" and employing the same definitions, would differ as to the amount of income. We do not know how common such disagreements would be, but we assume that they would not have any significant effect.

There is a deeper problem, however; the "true values" sought by the Bureau of the Census may not meet the requirements of some users of the statistics. The PES does not furnish any data on this; the census definitions were used as a basis for the PEs inquiries.

\section{"BETTER" METHODS LEAD TO GREATER ACCURACY}

Largely on a priori grounds, it has been held that the addition of certain features constitutes "improvement"-features like probing interviews, insistence on the "best" respondent, intensive training and supervision of personnel, in fact all the special features employed in the PES. These improvements, it is held, show up in more accurate data and statistics. Thus, it is argued that the PES was "better" than the census, in fact sufficiently accurate to evaluate the census.

There is an obvious limitation to this assumption. Both the census 
and the PES made use of interview methods and both were subject to some of the inherent limitations of such methods.

THE TIME LAG DID NOT ADVERSELY AFFECT

THE PES RESULTS

In our judgment, this assumption is false, at least as far as the results relating to the number of persons missed in the original enumeration are concerned. The PES check underestimated the extent of underenumeration in the 1950 census. One reason was that the PES interviewers were unable to account for all the missed people who changed their residence during the period between the onset of the census and the onset of the check.

The validity of the assumption in regard to the reporting of income is also important. The census inquiries about income in 1949 were conducted almost entirely in April and May 1950. The PES inquiries, also directed at 1949, were conducted almost entirely in August and September 1950. Was there any significant deterioration in the respondents' memories? We do not know; we assume that there was not, especially since the PES inquires were, at least a priori, better designed to restore or refresh memory.

\section{CERTAIN CENSUS OPERATIONS DID NOT REQUIRE CHECKING}

The punching, tabulating, reviewing, and publishing operations of the census were believed sufficiently controlled. The PES results do not indicate any of the errors that may have arisen during these operations. They reflect only the errors arising from three activities of the census; enumeration, editing, and coding.

\section{Gross Differences and Net Errors: Total Income of Persons}

The starting points for study of the PEs results are tables like Tables 1 and 2. They provide a first view of the sources of error in census statistics. Although we are dealing with gross differences rather than gross errors, we believe that the tables afford a fairly realistic conception of the relative contribution of each source of error. We shall not attempt any detailed description of the sources of error or of the gross differences, but we call attention to two results shown in the tables:

1. If the PES had been conducted on the entire population of the United States, about 40 per cent of the males and about 25 per cent of the females would have been assigned to different income classes from the ones they had been assigned to in the census. (These estimates exclude the contributions of nonresponse and of errors and differences in defining the population; not enumerating 


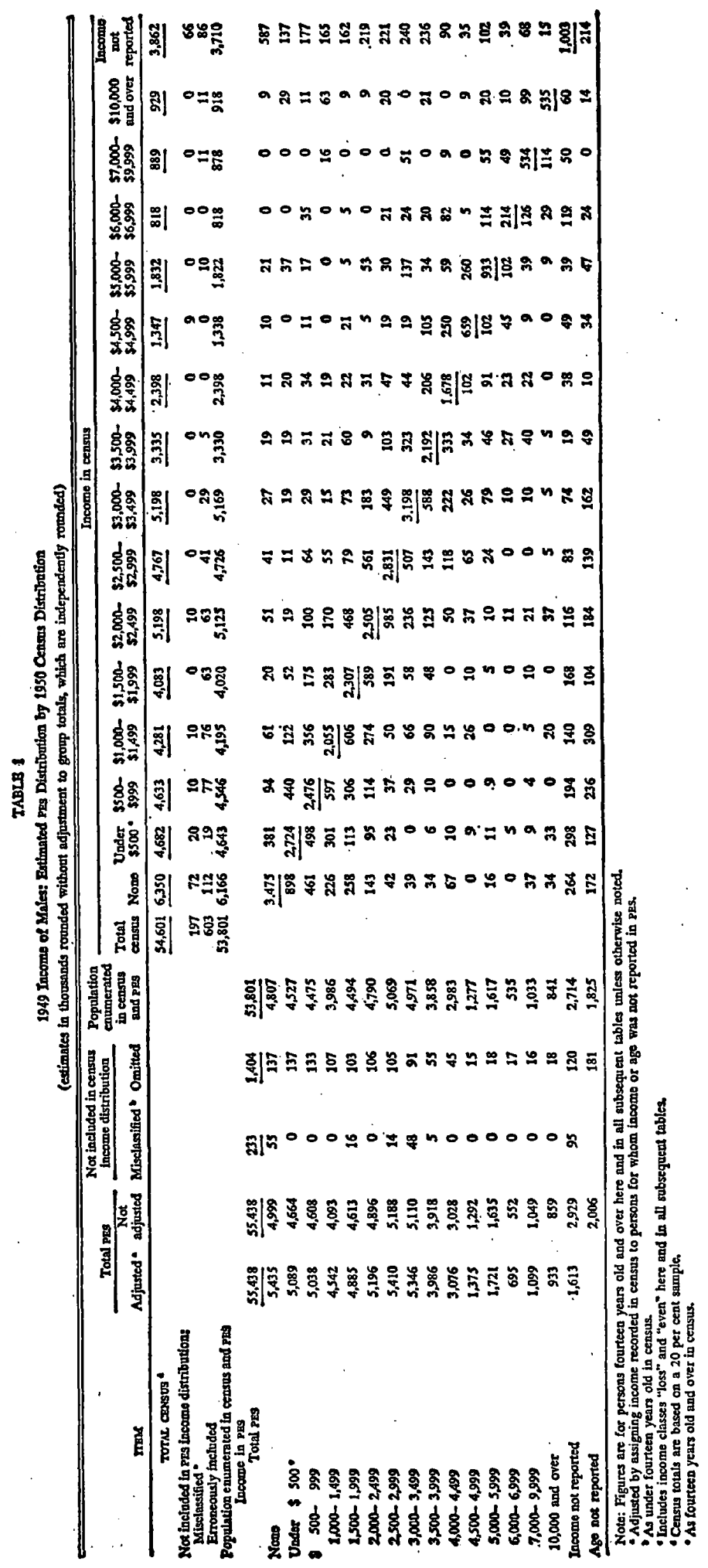




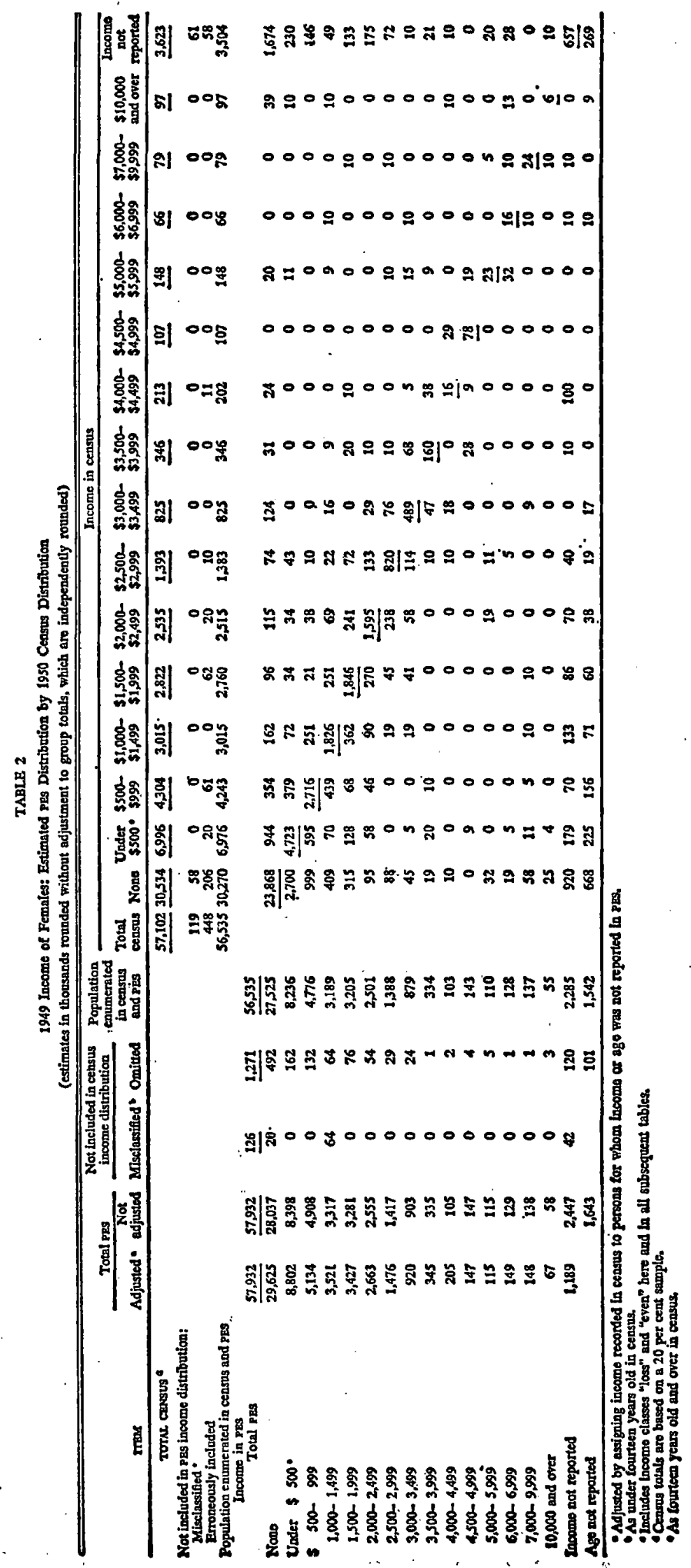


people, enumerating them in error, or differences in the classification of the population by age.)

2. There were more differences in which the PEs income classification was higher than that of the census than vice versa. Of the $18,454,000$ males who would have been classified differently, it is estimated that $11,149,000$ ( 60 per cent) were placed in the census in lower income classes than they would have been in the PES. Of the 11,925,000 females classified differently, an estimated $7,781,000$ (65 per cent) were placed in lower income classes in the census than they would have been in the PES. The major explanation for the greater difference among the females than among the males lies in the fact that the PEs found that a substantial number of females classified as "persons without income" in the census received very small amounts of income in 1949.

These estimates of gross difference are made relative to the class intervals shown in Tables 1 and 2. For grosser intervals, the divergence would be less.

\section{ACCURACY OF CENSUS STATISTICS}

Table 3 contains a comparison of the marginal totals of Tables 1 and 2. Because of the fairly high levels of sampling error in the PES estimates, no single figure in the table can legitimately be used to correct the corresponding census total. ${ }^{2}$ It is the general pattern that provides a basis for analysis. It is one of understatement of the number of income recipients in each class. There is estimated to have been a 9 per cent understatement in the total number of male income recipients and an 18 per cent understatement in the number of female recipients; about 4 million persons in each case. If the census and PES "income not reported" totals were to be proportionately distributed among the other classes, then the estimated discrepancy of 8 million recipients for males and females combined would be reduced to about 5 million. There were two major causes for this discrepancy; the underenumeration of the population and the misclassification of persons who actually acquired income in 1949 as "persons without income."

\section{NONRESPONSE IN THE PES}

The PES income distributions were derived from "adjusted PES totals." These totals were derived after substituting the census classifications, where available, for cases in which the PES was not

\footnotetext{
${ }^{2}$ Because of the great effort that would have been required, estimates of sampling error have not been prepared. Some information on the extent of sampling error can be furnished, on request, by the authors.
} 


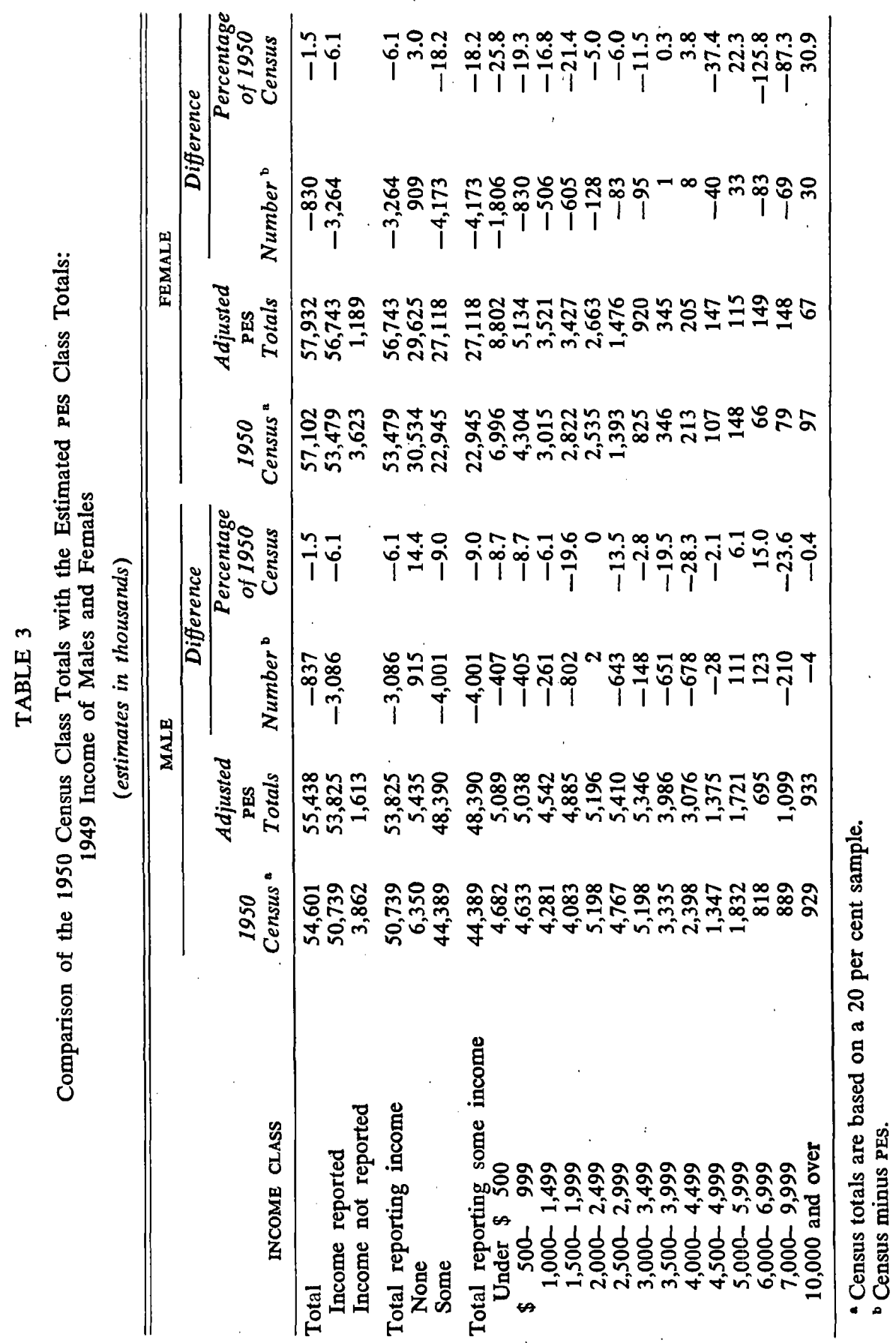




\section{950 C E N S U S A N D PES}

able to obtain responses. We recognize that this is a debatable practice. It was done on the premise that it would provide the best possible response in each case. Actually, as Tables 1 and 2 indicate, the unadjusted PES nonresponse rates were quite substantial, about 8 per cent. The major reason for this level of nonresponse was the insistence on obtaining information from the "best" respondents in the re-enumerative check. If, after repeated calls, a best respondent could not be located, the PES interviewer was instructed to record a nonresponse instead of seeking out an available respondent. Another factor, which also accounts for some of the divergence in the data of the census and the PES, is that more stringent coding rules were used for the responses in the re-enumerative check. In the PES, if one type of income was not reported, total income was coded as "not reported." On the other hand, under certain conditions, the entry for a type of income was assumed in the census to be "none" if it was not reported, thus permitting the assignment of a numerical code for total income.

\section{Distributions of Total Income of Persons}

We turn now to the results. Keeping in mind the following facts, we shall first examine Tables 4 through 8:

1. The "1950 census" medians and distributions were transcribed directly from the summary volume of the 1950 census. $^{3}$

2. The "PEs" medians and distributions were derived from "adjusted PEs totals" obtained from tables like Tables 1 and 2 . These totals are based on samples of approximately 10,000 persons enumerated in the 1950 census and 1,800 persons erroneously omitted from the 1950 census.

3. "Persons without income," the zero class, are not reflected in the medians.

4. All of the PES estimates are subject to fairly high sampling errors. For this reason, the medians have been rounded to the tens digit. No single figure is precise enough to be used to "correct" a census statistic; all that we can point to are general tendencies or patterns.

\section{MEDIANS}

Table 4 compares census medians with those estimated from the re-enumerative check. Results are given for males and females separately, classified by color and by residence.

Despite the levels of gross difference in the data and the levels of

' 1950 Census of Population, Vol. II, Characteristics of the Population, Part 1. United States Summary. 
net error in the class totals, not one estimated difference between medians is greater than $\$ 100$. The PES medians are estimated to be higher than those of the census for the nonwhite and urban-male components of the population. For white females and rural males, the PES medians are estimated to be lower. The latter can be explained by the disproportionate addition of recipients of income to the low-income classes.

\section{INCOME RECIPIENTS}

The PES found significantly higher proportions of persons with income than did the census. The understatements in the census appear to be most pronounced for the nonwhite population (estimated at almost 8 percentage points for males and 6 percentage points for females) and for the urban-female population (estimated at almost 6 percentage points).

\section{DISTRIBUTION}

Comparison of the distributions in Tables 4 through 8 , class by class, reveals no striking patterns of difference. The addition of income recipients to the low-income classes accounts, in part, for the finding that, for the female population, the relative sizes of the income classes above $\$ 2,000$ tend to have been overstated in the census. By and large, however, the similarities appear to be more striking than the differences.

\section{IDENTICAL POPULATION}

The differences between the statistics of the 1950 census and the PES, summarized in Tables 4 through 8 , result from more than gross differences in the reporting and coding of the amount of income. As Tables 1 and 2 indicate, "coverage" errors, errors in the reporting of age, nonresponse, and errors in the designation of

TABLE 4

Comparison of the 1950 Census Medians with the Estimated PES Medians: 1949 Income of All Males and Females, by Color and by Residence

\begin{tabular}{|c|c|c|c|c|c|c|}
\hline \multirow[b]{2}{*}{ GROUP } & \multicolumn{3}{|c|}{ MALE } & \multicolumn{3}{|c|}{ FEMALE } \\
\hline & $\begin{array}{l}1950 \\
\text { Census }\end{array}$ & PES & Difference $^{\text {a }}$ & $\begin{array}{c}1950 \\
\text { Census }\end{array}$ & PES & Difference \\
\hline All males or females & $\$ 2,430$ & $\$ 2,450$ & $\$-20$ & $\$ 1,030$ & $\$ 960$ & $\$ 70$ \\
\hline $\begin{array}{l}\text { White } \\
\text { Nonwhite }\end{array}$ & $\begin{array}{l}2,570 \\
1,340\end{array}$ & $\begin{array}{l}2,600 \\
1,350\end{array}$ & $\begin{array}{l}-30 \\
-10\end{array}$ & $\begin{array}{r}1,140 \\
580\end{array}$ & $\begin{array}{r}1,050 \\
640\end{array}$ & $\begin{array}{r}90 \\
-60\end{array}$ \\
\hline $\begin{array}{l}\text { Urban } \\
\text { Rural nonfarm } \\
\text { Rural farm }\end{array}$ & $\begin{array}{l}2,780 \\
2,070 \\
1,340\end{array}$ & $\begin{array}{l}2,810 \\
2,040 \\
1,300\end{array}$ & $\begin{array}{r}-30 \\
30 \\
40\end{array}$ & $\begin{array}{r}1,230 \\
720 \\
460\end{array}$ & $\begin{array}{r}1,160 \\
620 \\
450\end{array}$ & $\begin{array}{r}70 \\
100 \\
10\end{array}$ \\
\hline
\end{tabular}

a Census minus pes. 


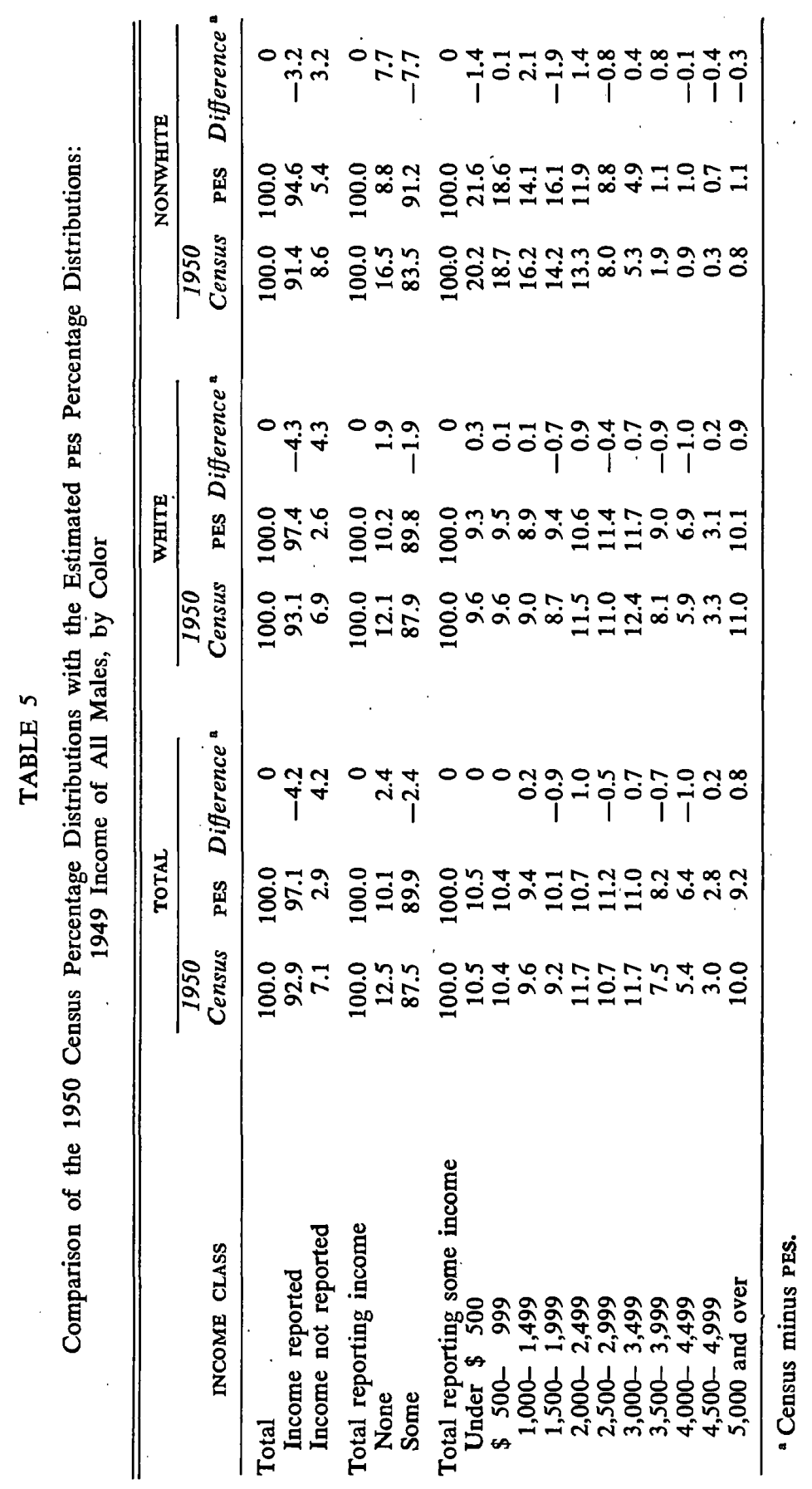




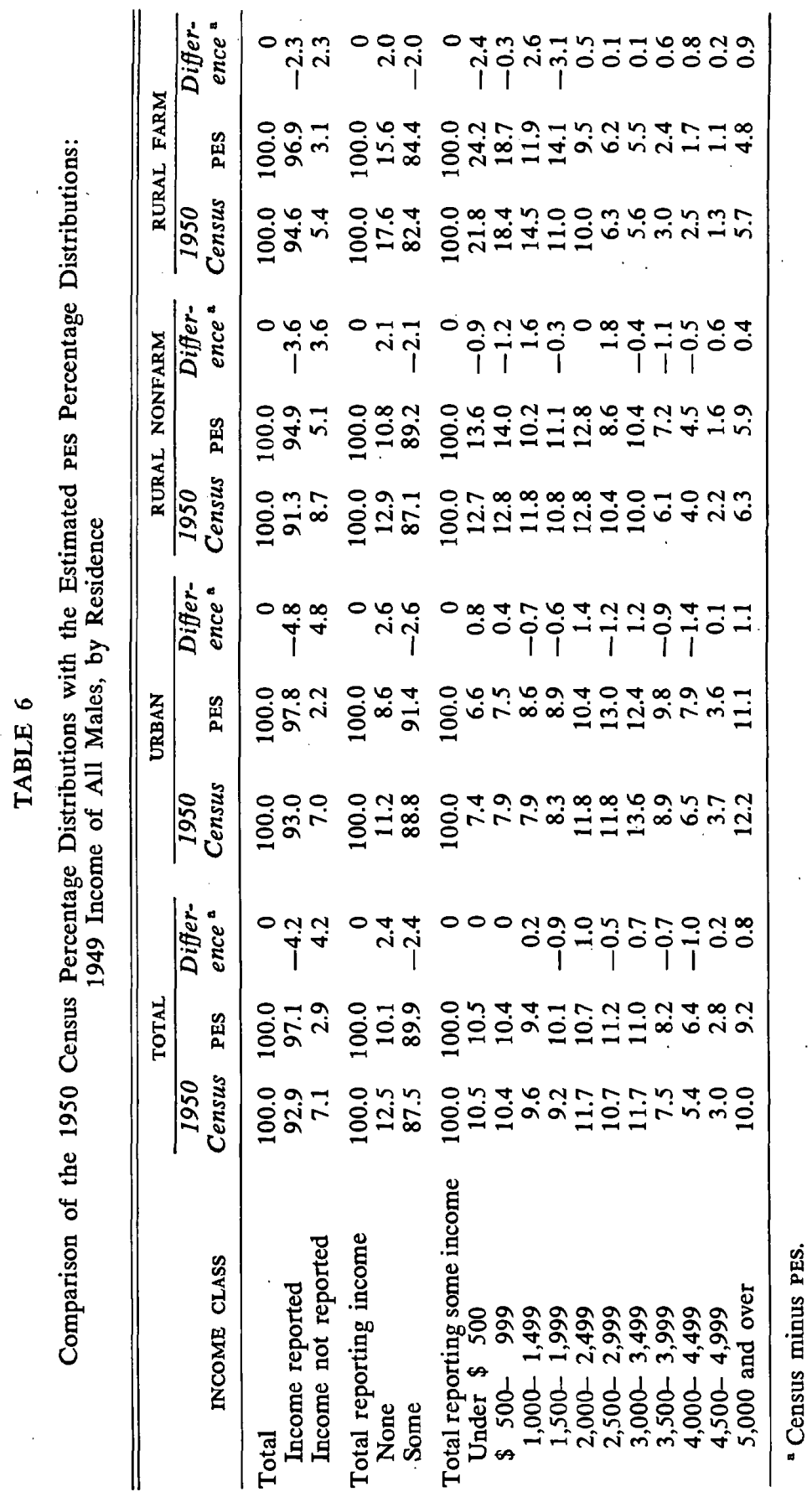




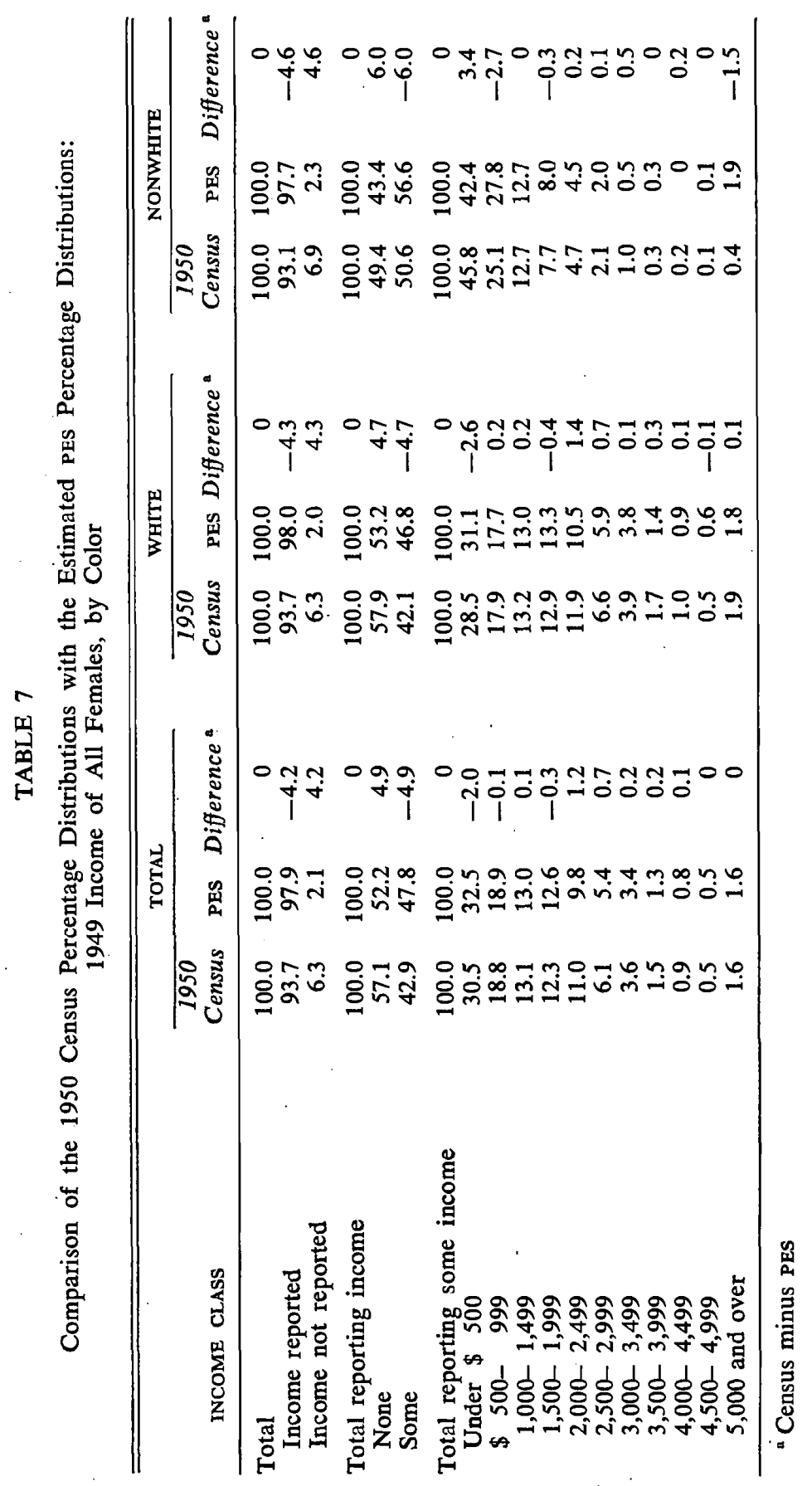




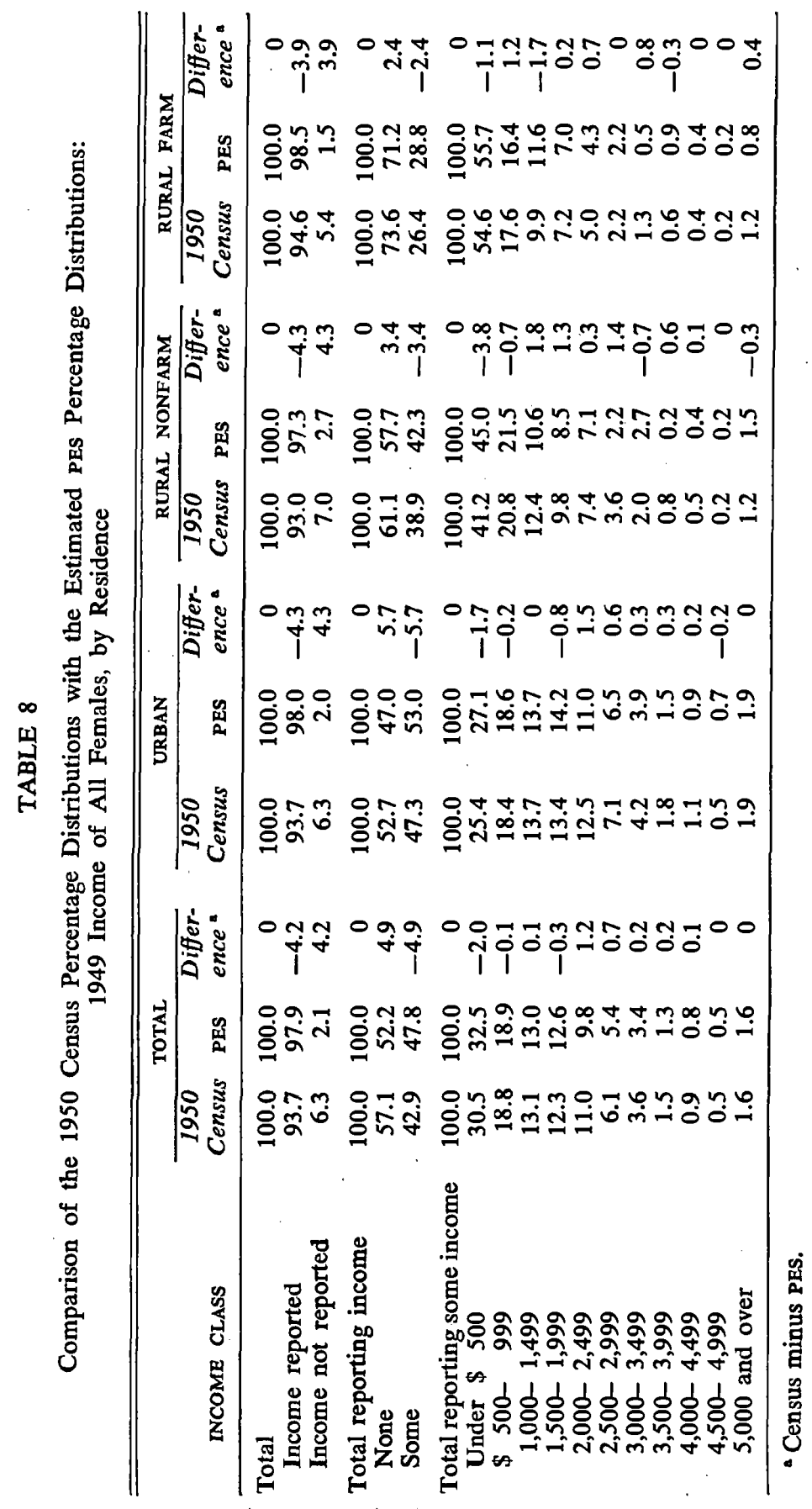


persons as "persons with income" all contribute to the differences in Tables 4 through 8.

One major factor was the difference in the reporting and coding of income. To deal with this factor by itself, we had to define an "identical population"; the persons who were classified as "persons with income" in both the 1950 census and the PES. We exclude cases of critical difference in the reporting of age, coverage error, and nonresponse. We thus have a "population" in which there are two reports of income in 1949 for each individual. As we have noted, there is evidence of directional differences between the 1950 census and PES reports of income for this "identical population." The effect of this directional difference on the income distribution is shown in Tables 9 through 13.

TABLE 9

Comparison of the 1950 Census Medians with the Estimated PES Medians: 1949 Income of Identical Males and Females, by Color and by Residence

\begin{tabular}{|c|c|c|c|c|c|c|}
\hline \multirow[b]{2}{*}{ GROUP } & \multicolumn{3}{|c|}{ MALE } & \multicolumn{3}{|c|}{ FEMALE } \\
\hline & 1950 Census & PES & $\overline{\text { Difference }}$ & 1950 Census & PES & Difference \\
\hline All males or females & $\$ 2,520$ & $\$ 2,580$ & $\$-60$ & $\$ 1,080$ & $\$ 1,140$ & $\$-60$ \\
\hline $\begin{array}{l}\text { White } \\
\text { Nonwhite }\end{array}$ & $\begin{array}{l}2,640 \\
1,320\end{array}$ & $\begin{array}{l}2,700 \\
1,430\end{array}$ & $\begin{array}{r}-60 \\
-110\end{array}$ & $\begin{array}{r}1,190 \\
620\end{array}$ & $\begin{array}{r}1,250 \\
680\end{array}$ & $\begin{array}{l}-60 \\
-60\end{array}$ \\
\hline $\begin{array}{l}\text { Urban } \\
\text { Rural nonfarm } \\
\text { Rural farm }\end{array}$ & $\begin{array}{l}2,860 \\
2,150 \\
1,400\end{array}$ & $\begin{array}{l}2,910 \\
2,200 \\
1,420\end{array}$ & $\begin{array}{l}-50 \\
-50 \\
-20\end{array}$ & $\begin{array}{r}1,280 \\
740 \\
450\end{array}$ & $\begin{array}{r}1,340 \\
740 \\
480\end{array}$ & $\begin{array}{r}-60 \\
0 \\
-30\end{array}$ \\
\hline
\end{tabular}

a Census minus PES.

TABLE 10

Comparison of the 1950 Census Percentage Distributions with the Estimated PES Percentage Distributions: 1949 Income of Identical Males, by Color

\begin{tabular}{|c|c|c|c|c|c|c|c|c|c|}
\hline \multirow[b]{2}{*}{ INCOME CLASS } & \multicolumn{3}{|c|}{ TOTAL } & \multicolumn{3}{|c|}{ WHITE } & \multicolumn{3}{|c|}{ NONWHITE } \\
\hline & $\begin{array}{l}1950 \\
\text { Census }\end{array}$ & PES & $\begin{array}{l}\text { Differ- } \\
\text { ence }\end{array}$ & $\begin{array}{c}1950 \\
\text { Census }\end{array}$ & PES & $\begin{array}{l}\text { Differ- } \\
\text { ence }^{\text {a }}\end{array}$ & $\begin{array}{l}1950 \\
\text { Census }\end{array}$ & PES & $\begin{array}{l}\text { Differ- } \\
\text { ence }\end{array}$ \\
\hline Total & 100.0 & 100.0 & 0 & 100.0 & 100.0 & 0 & 100.0 & 100.0 & 0 \\
\hline Under $\$ 500$ & 9.5 & 8.7 & 0.8 & 8.5 & 7.8 & 0.7 & 20.5 & 18.0 & 2.5 \\
\hline$\$ 500-999$ & 10.0 & 9.5 & 0.5 & 9.2 & 8.6 & 0.6 & 18.6 & 19.2 & -0.6 \\
\hline $1,000-1,499$ & 9.1 & 8.9 & 0.2 & 8.4 & 8.4 & 0 & 16.9 & 14.8 & 2.1 \\
\hline $1,500-1,999$ & 9.2 & 10.1 & -0.9 & 9.0 & 9.7 & -0.7 & 11.6 & 14.5 & -2.9 \\
\hline $2,000-2,499$ & 11.8 & 11.0 & 0.8 & 11.7 & 10.8 & 0.9 & 13.9 & 12.5 & 1.4 \\
\hline $2,500-2,999$ & 11.1 & 11.9 & -0.8 & 11.3 & 12.0 & -0.7 & 8.4 & 11.0 & -2.6 \\
\hline $3,000-3,499$ & 12.2 & 11.6 & 0.6 & 12.8 & 12.2 & 0.6 & 5.8 & 5.7 & 0.1 \\
\hline $3,500-3,999$ & 8.0 & 8.9 & -0.9 & 8.6 & 9.6 & -1.0 & 1.9 & 1.2 & 0.7 \\
\hline $4,000-4,499$ & 5.8 & 7.0 & -1.2 & 6.3 & 7.6 & -1.3 & 1.0 & 1.3 & -0.3 \\
\hline $4,500-4,999$ & 3.1 & 3.1 & 0 & 3.3 & 3.3 & 0 & 0.4 & 1.0 & -0.6 \\
\hline 5,000 and over & 10.1 & 9.2 & 0.9 & 10.9 & 10.0 & 0.9 & 1.0 & 0.9 & 0.1 \\
\hline
\end{tabular}

a Census minus PES. 


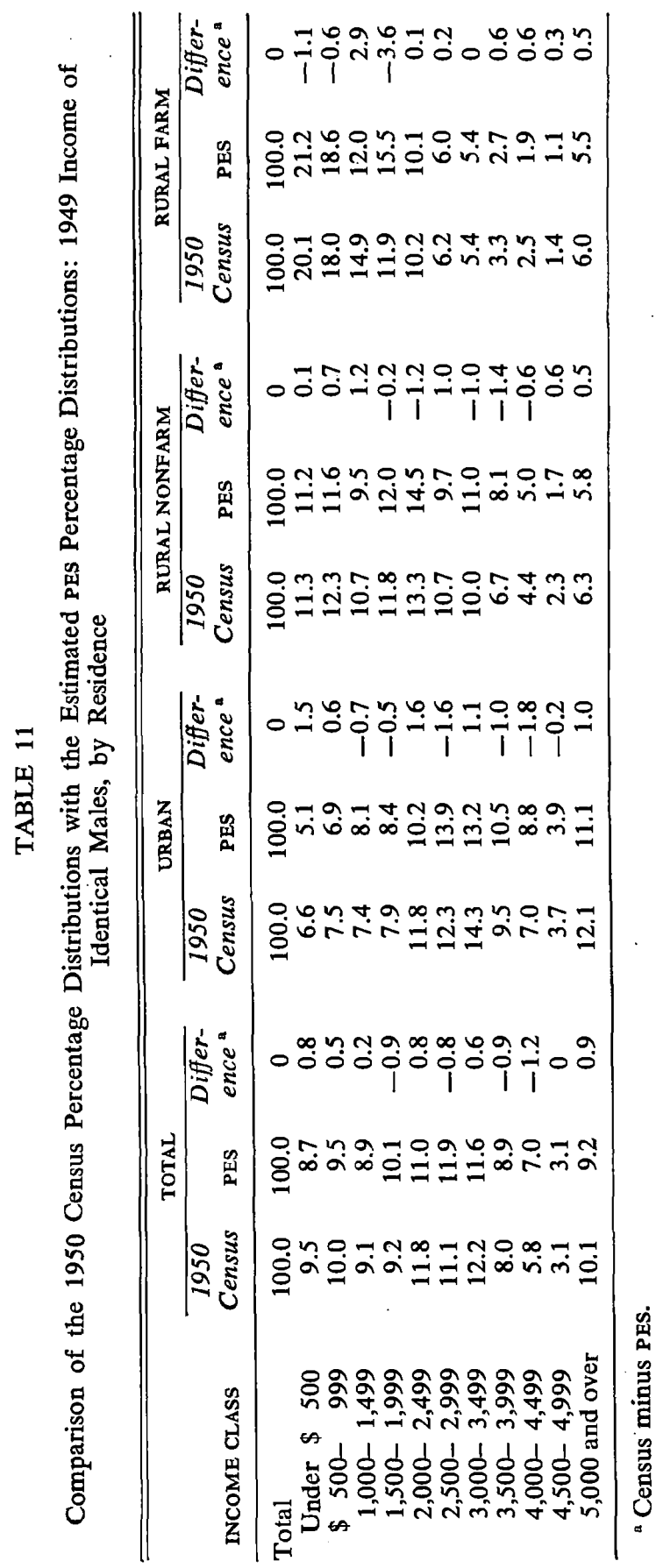


I 950 CENSUS A N D. PES

TABLE 12

Comparison of the 1950 Census Percentage Distributions with the Estimated PES Percentage

Distributions: 1949 Income of Identical Females, by Color

\begin{tabular}{|c|c|c|c|c|c|c|c|c|c|}
\hline \multirow[b]{2}{*}{ INCOME CLASS } & \multicolumn{3}{|c|}{ TOTAL } & \multicolumn{3}{|c|}{ WHITE } & \multicolumn{3}{|c|}{ NoNWHITE } \\
\hline & $\begin{array}{c}1950 \\
\text { Census }\end{array}$ & PES & $\begin{array}{l}\text { Differ- } \\
\text { ence }^{\text {a }}\end{array}$ & $\begin{array}{c}\text { I950 } \\
\text { Census. }\end{array}$ & PES & $\begin{array}{c}\text { Differ- } \\
\text { ence }\end{array}$ & $\begin{array}{c}1950 \\
\text { Census }\end{array}$ & PES & $\begin{array}{l}\text { Differ- } \\
\text { ence }\end{array}$ \\
\hline Total & 100.0 & 100.0 & 0 & 100.0 & 100.0 & 0 & 100.0 & 100.0 & 0 \\
\hline Under $\$ 500$ & 28.9 & 27.3 & 1.6 & 27.1 & 25.7 & 1.4 & 43.2 & 39.6 & 3.6 \\
\hline$\$ 500-999$ & 18.8 & 18.7 & 0.1 & 17.8 & 17.3 & 0.5 & 27.1 & 29.3 & -2.2 \\
\hline $1,000-1,499$ & 13.6 & 14.0 & -0.4 & 13.6 & 13.9 & -0.3 & 13.7 & 15.3 & -1.6 \\
\hline $1,500-1,999$ & 12.9 & 14.2 & -1.3 & 13.7 & 15.2 & -1.5 & 7.1 & 6.5 & 0.6 \\
\hline $2,000-2,499$ & 11.8 & 11.5 & 0.3 & 12.7 & 12.4 & 0.3 & 4.3 & 4.5 & -0.2 \\
\hline $2,500-2,999$ & 6.4 & 6.3 & 0.1 & 6.9 & 6.8 & 0.1 & 2.6 & 2.7 & -0.1 \\
\hline $3,000-3,499$ & 3.5 & 4.2 & -0.7 & 3.8 & 4.7 & -0.9 & 1.2 & 0.7 & 0.5 \\
\hline $3,500-3,999$ & 1.6 & 1.5 & 0.1 & 1.7 & 1.6 & 0.1 & 0.4 & 0.5 & -0.1 \\
\hline $4,000-4,499$ & 0.4 & 0.4 & 0 & 0.5 & 0.5 & 0 & 0 & 0 & 0 \\
\hline $4,500-4,999$ & 0.5 & 0.7 & -0.2 & 0.6 & 0.8 & -0.2 & 0.1 & 0.1 & 0 \\
\hline 5,000 and over & 1.5 & 1.2 & 0.3 & 1.6 & 1.3 & 0.3 & 0.4 & 0.9 & -0.5 \\
\hline
\end{tabular}

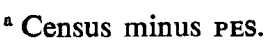

MEDIANS

Table 9 shows that this difference produced an error of about $\$ 60$, on the average, in the census medians. This demonstrates the stability of the median as a measure of central tendency.

\section{DISTRIBUTIONS}

The gross differences in reporting produced no clear shift in any of the distributions shown in Tables 10 through 13, except that in general, both the lowest and the highest classes were reported in the census as having somewhat too high proportions of the population.

For the "identical" male population, the average absolute deviation between the 1950 census and PES percentages was about 0.7 of a percentage point for the ten income classes from $\$ 1$ to $\$ 4,999$. For the female population, the corresponding average absolute deviation was about 0.5 of a percentage point.

\section{Distributions of Total Income of Families}

The inquiries used in the 1950 census to obtain information on family income are reproduced in the Appendix. The method of obtaining the data was as follows:

If the head of a family was listed on a sample line on a census schedule, he (or his respondent) was asked three questions. His own total income was computed and coded from the answers. Next, 


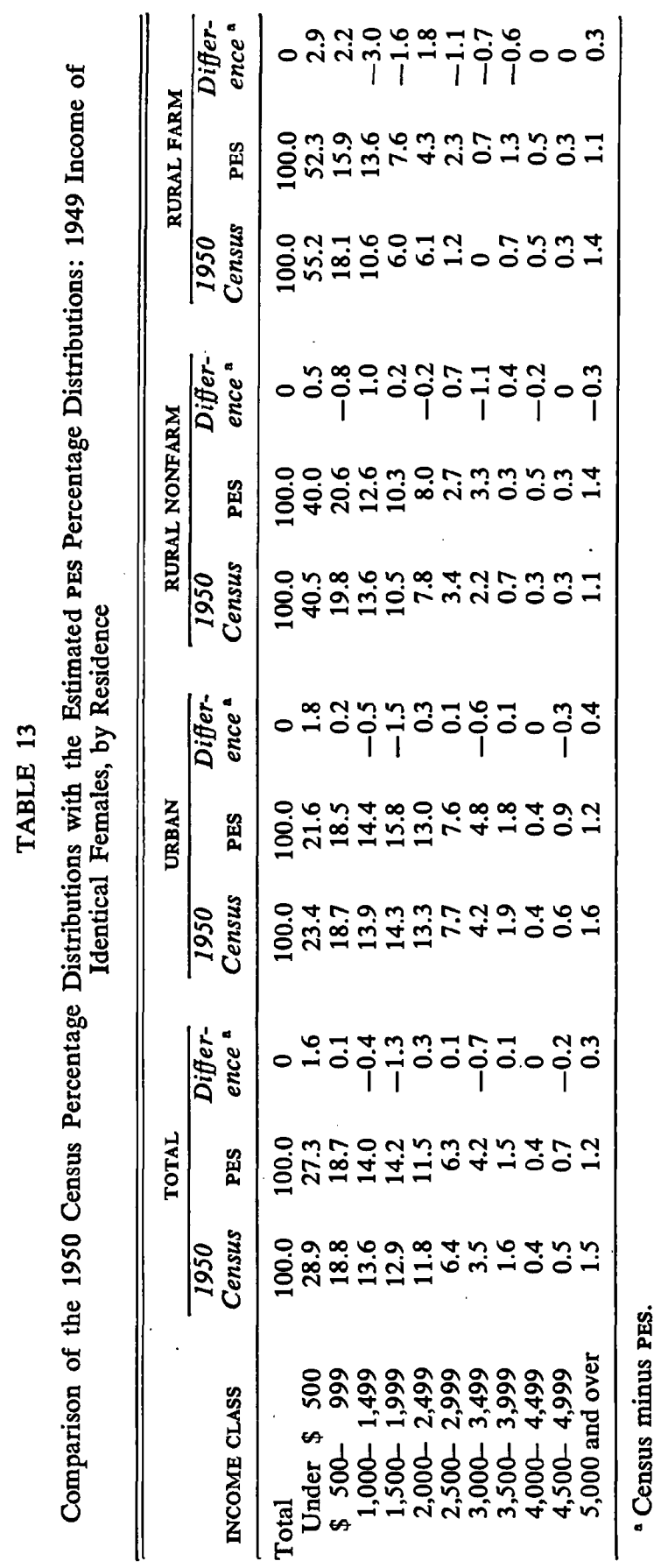


essentially the same three questions were asked concerning all the other members of his family. A single figure was recorded as the sum of each type of income for the remaining members of the family. The totals of the three types of income were then added to the total income of the family head to produce a total for family income.

In the PES, a much more elaborate procedure was employed. A complete set of income questions was asked of each member of each family.

The method of tabulation of the data for the approximately 5,500 families in the "family income subsample" precludes any direct evaluation of the family income distributions of the 1950 census. We have not been able to project the sample results to universe figures. The results are based on unadjusted totals derived from the same type of table as Tables 1 and 2 . The picture of the family income data is essentially the same as that of the personal income data; a large number of disagreements in classification, of coverage errors, of errors in the definition of families, all leading to sizeable differences in the income class totals.

Again, two sets of results have been prepared, one based on all families in the sample and the other based on "identical" families. In the former case, the differences between the medians and distributions reflect all sources of error detected by the re-enumerative check. In the latter case, the differences reflect only errors arising from the reporting and coding of income. An "identical family" is one that was properly enumerated, received income in 1949, and where the PES and census agree on family type and size.

The available results are presented in Tables 14 through 16 . The term "original" is used to describe the tabulation of the census data; the term "recheck" refers to the tabulation of the PES data from the same sample. Results are available only by residence.

TABLE 14

Comparison of Original and Recheck Medians: 1949 Income of Families, by Residence

\begin{tabular}{lrrrrrrr}
\hline \hline & \multicolumn{3}{c}{ ALL FAMILIES } & & \multicolumn{3}{c}{ DENTICAL FAMILIES } \\
\cline { 2 - 3 } \multicolumn{1}{c}{ GROUP } & Original & Recheck & Difference & & Original & Recheck & Difference \\
\hline All families & $\$ 3,210$ & $\$ 3,480$ & $\$-270$ & & $\$ 3,260$ & $\$ 3,510$ & $\$-250$ \\
Urban & 3,540 & 3,860 & -320 & & 3,610 & 3,920 & -310 \\
Rural nonfarm & 2,700 & 3,020 & -320 & & 2,710 & 2,990 & -280 \\
Rural farm & 1,820 & 1,950 & -130 & & 1,850 & 1,900 & -50 \\
\hline
\end{tabular}

- Original minus recheck. 


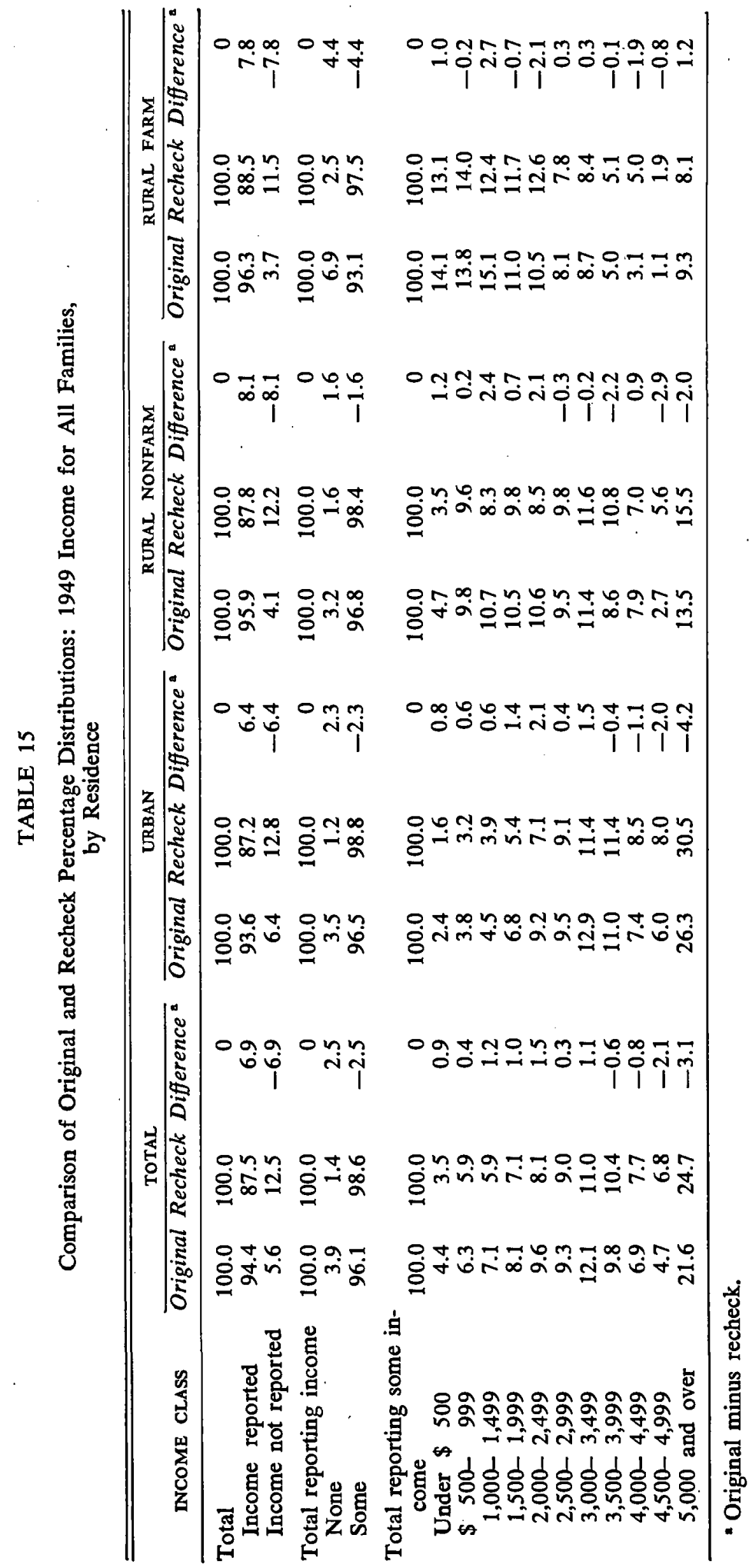




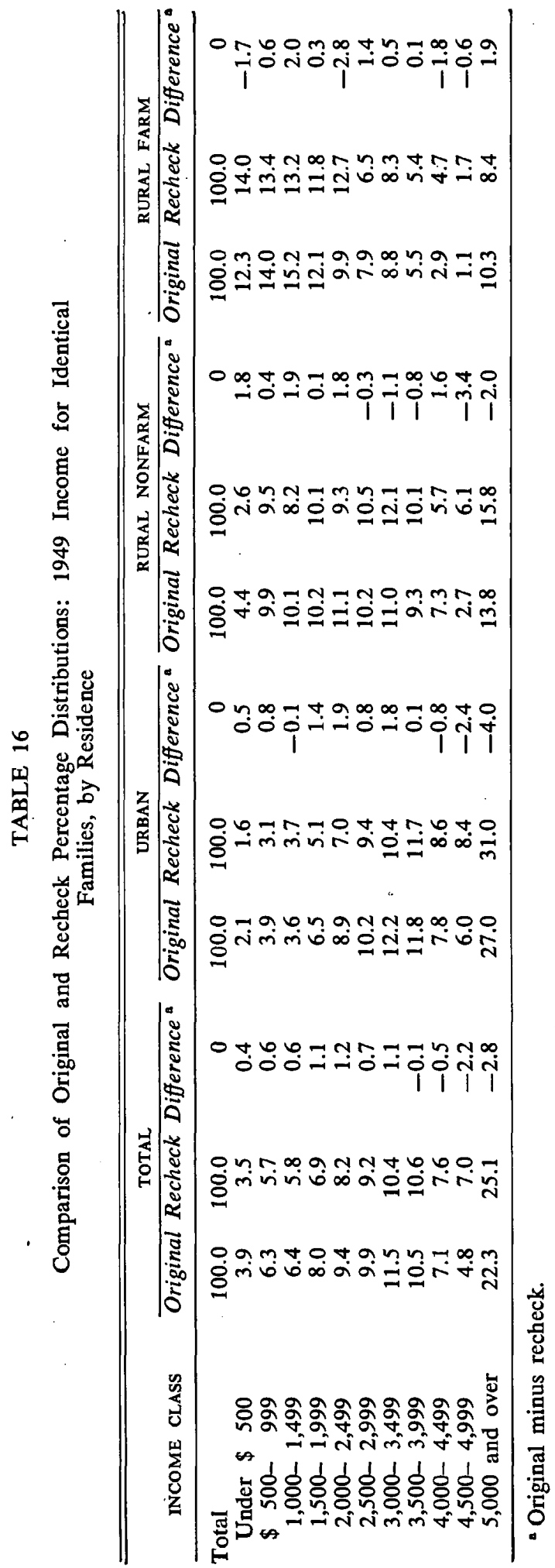




\section{MEDIANS ${ }^{4}$}

For the urban and rural-nonfarm cases, the original medians are about $\$ 300$ less than the recheck medians, with essentially the same result for identical families as for all families. For the ruralfarm cases, the original and recheck medians appear to be somewhat closer together, with a difference of $\$ 130$ for all families and of $\$ 50$ for identical families. As in the case of personal income, some of the 1950 census medians for family income were estimated to have been too high because the additional income recipients picked up by the PES appear to have been concentrated in the low income class. We would guess (no direct evidence is available) that failing to include the income of persons other than the family head was an important factor in the understatement of the census medians. $^{5}$

\section{FAMILIES WITHOUT INCOME}

In the census tabulations, this group is included in the class "income under \$500." The results indicate that about two and one-half times as many families were included in that class in the census (about 4 per cent) as should have been (about 1.5 per cent).

\section{DISTRIBUTIONS}

Tables 15 and 16 show evidence of a small but definite directional bias in the census distributions. The proportions in the lowest income classes appear to have been overstated, in general, while the proportions in the income classes beginning with $\$ 3,500$ appear to have been understated. (There are some differences depending on the residence of the families.) The fact that the results shown in Table 15 (all families) parallel those in Table 16 (identical families) indicates that the underreporting of the amount of income was the most significant source of error in the census distributions.

\section{Distributions of Income of Persons, by Type of Income}

Tables 17 through 20 present the PES results relating to income by type; wages and salaries, income from self-employment, and income from all other sources. Again we have not been able to

\footnotetext{
- The medians were defined on a somewhat different basis than the published 1950 census medians for family income. The published figures include the "families with no income" in the computation; the figures in this report do not.

'The editing rules employed in the 1950 census probably had some impact. There were situations in which a nonresponse to a specific inquiry could be treated as a response of "none."
} 
I 950 CENSUS A N D PES

TABLE 17

Comparison of Original and Recheck Medians: 1949 Income of Males and Females, by Type of Income

\begin{tabular}{|c|c|c|c|c|c|c|}
\hline \multirow[b]{2}{*}{ SOURCE OF INCOME } & \multicolumn{3}{|c|}{ MALE } & \multicolumn{3}{|c|}{ FEMALE } \\
\hline & Original & Recheck & Difference $^{\mathrm{a}}$ & $\overline{\text { Original }}$ & Recheck & Difference \\
\hline Total income ${ }^{b}$ & $\$ 2,430$ & $\$ 2,450$ & $\$-20$ & $\$ 1,030$ & $\$ 960$ & $\$ 70$ \\
\hline Wages and salaries & 2,460 & 2,540 & -80 & 1,200 & 1,130 & 70 \\
\hline Self-employment & 1,920 & 1,760 & 160 & 930 & 760 & 170 \\
\hline All other income & 470 & 460 & 10 & 450 & 420 & 30 \\
\hline
\end{tabular}

a Original minus recheck.

${ }^{b}$ Based on actual 1950 census tabulations and projections of PES results to the universal level.

compare the actual census tabulations with the PES data projected to universe levels. As in the case of family income, the comparisons are limited to the sample itself, and thus the terms "original" and "recheck" are used. Also the results relate only to all individuals in the sample; no results are available for "identical" individuals. Thus the results reflect all sources of error and difference, errors in defining the population and nonresponse as well as differences in the reporting of the amount of income.

TABLE 18

Comparison of Original and Recheck Percentage Distributions: 1949 Income from Wages or Salary, Males and Females

\begin{tabular}{|c|c|c|c|c|c|c|}
\hline \multirow{2}{*}{ INCOME CLASS } & \multicolumn{3}{|c|}{ MALE } & \multicolumn{3}{|c|}{ FEMALE } \\
\hline & Original & Recheck & Difference ${ }^{a}$ & Original & Recheck & $\overline{\text { Difference }}$ \\
\hline Total & 100.0 & 100.0 & 0 & 100.0 & 100.0 & 0 \\
\hline Income reported & 94.7 & 93.9 & 0.8 & 94.9 & 94.5 & 0.4 \\
\hline Income not reported & 5.3 & 6.1 & -0.8 & 5.1 & 5.5 & -0.4 \\
\hline Total reporting income & 100.0 & 100.0 & 0 & 100.0 & 100.0 & 0 \\
\hline None & 31.5 & 31.1 & 0.4 & 69.6 & 67.2 & 2.4 \\
\hline Some & 68.5 & 68.9 & -0.4 & 30.4 & 32.8 & -2.4 \\
\hline Total reporting some income & 100.0 & 100.0 & 0 & 100.0 & 100.0 & 0 \\
\hline Under $\$ 500$ & 11.3 & 11.9 & -0.6 & 27.6 & 28.9 & -1.3 \\
\hline$\$ 500-999$ & 9.0 & 9.0 & 0 & 16.8 & 17.7 & -0.9 \\
\hline $1,000-1,499$ & 8.4 & 7.7 & 0.7 & 14.0 & 12.6 & 1.4 \\
\hline $1,500-1,999$ & 9.4 & 8.9 & 0.5 & 13.3 & 14.1 & -0.8 \\
\hline $2,000-2,499$ & 12.8 & 11.5 & 1.3 & 13.5 & 12.1 & 1.4 \\
\hline $2,500-2,999$ & 11.2 & 12.4 & -1.2 & 8.0 & 7.4 & 0.6 \\
\hline $3,000-3,499$ & 13.5 & 12.2 & 1.3 & 3.3 & 3.9 & -0.6 \\
\hline $3,500-3,999$ & 8.6 & 9.5 & -0.9 & 1.7 & 1.2 & 0.5 \\
\hline $4,000-4,499$ & 4.5 & 5.8 & -1.3 & 0.7 & 0.5 & 0.2 \\
\hline $4,500-4,999$ & 3.1 & 3.1 & 0 & 0.5 & 0.6 & -0.1 \\
\hline 5,000 and over & 8.2 & 8.1 & 0.1 & 0.5 & 0.9 & -0.4 \\
\hline
\end{tabular}

"Original minus recheck. 
TABLE 19

Comparison of Original and Recheck Percentage Distributions: 1949 Income from SelfEmployment, Males and Females

\begin{tabular}{|c|c|c|c|c|c|c|}
\hline \multirow[b]{2}{*}{ INCOME CLASS } & \multicolumn{3}{|c|}{ MALE } & \multicolumn{3}{|c|}{ FEMALE } \\
\hline & $\overline{\text { Original }}$ & Recheck & Difference $^{a}$ & Original & Recheck & Difference $^{a}$ \\
\hline Total & 100.0 & 100.0 & 0 & 100.0 & 100.0 & 0 \\
\hline Income reported & 94.4 & 93.4 & 1.0 & 94.6 & 94.1 & 0.5 \\
\hline Income not reported & 5.6 & 6.6 & -1.0 & 5.4 & 5.9 & -0.5 \\
\hline Total reporting income & 100.0 & 100.0 & 0 & 100.0 & 100.0 & 0 \\
\hline None & 83.7 & 82.4 & 1.3 & 96.5 & 96.9 & -0.4 \\
\hline Some & 16.3 & 17.6 & -1.3 & 3.5 & 3.1 & 0.4 \\
\hline Total reporting some income & 100.0 & 100.0 & 0 & 100.0 & 100.0 & 0 \\
\hline Under $\$ 500$ & 17.6 & 20.1 & -2.5 & 37.9 & 40.8 & -2.9 \\
\hline$\$ 500-999$ & 14.8 & 14.5 & 0.3 & 14.2 & 17.9 & -3.7 \\
\hline $1,000-1,499$ & 10.5 & 10.0 & 0.5 & 5.1 & 7.8 & -2.7 \\
\hline $1,500-1,999$ & 8.5 & 10.6 & -2.1 & 9.4 & 8.0 & 1.4 \\
\hline $2,000-2,499$ & 7.9 & 9.7 & -1.8 & 6.7 & 6.3 & 0.4 \\
\hline $2,500-2,999$ & 5.8 & 6.0 & -0.2 & 4.2 & 1.6 & 2.6 \\
\hline $3,000-3,499$ & 8.8 & 5.7 & 3.1 & 6.1 & 0.7 & 5.4 \\
\hline $3,500-3,999$ & 6.0 & 6.4 & -0.4 & 0.5 & 0.6 & -0.1 \\
\hline $4,000-4,499$ & 4.2 & 3.2 & 1.0 & 5.8 & 5.9 & -0.1 \\
\hline $4,500-4,999$ & 1.9 & 1.8 & 0.1 & 1.1 & 0.5 & 0.6 \\
\hline 5,000 and over & 13.7 & 11.9 & 1.8 & 9.2 & 10.0 & -0.8 \\
\hline
\end{tabular}

Original minus recheck.

TABLE 20

Comparison of Original and Recheck Percentage Distributions: 1949 Income from Sources other than Earnings, Males and Females

\begin{tabular}{|c|c|c|c|c|c|c|}
\hline \multirow[b]{2}{*}{ INCOME CLASS } & \multicolumn{3}{|c|}{ MALE } & \multicolumn{3}{|c|}{ FEMALE } \\
\hline & $\overline{\text { Original }}$ & Recheck & Difference ${ }^{a}$ & Original & Recheck & $\overline{\text { Difference }}{ }^{a}$ \\
\hline Total & 100.0 & 100.0 & 0 & 100.0 & 100.0 & 0 \\
\hline Income reported & 94.4 & 93.6 & 0.8 & 94.3 & 94.1 & 0,2 \\
\hline Income not reported & 5.6 & 6.4 & -0.8 & 5.7 & 5.9 & -0.2 \\
\hline Total reporting income & 100.0 & 100.0 & 0 & 100.0 & 100.0 & 0 \\
\hline None & 78.2 & 68.7 & 9.5 & 87.7 & 81.0 & 6.7 \\
\hline Some & 21.8 & 31.3 & -9.5 & 12.3 & 19.0 & -6.7 \\
\hline Total reporting some income & 100.0 & 100.0 & 0 & 100.0 & 100.0 & 0 \\
\hline Under $\$ 500$ & 53.7 & 55.0 & -1.3 & 56.1 & 59.6 & -3.5 \\
\hline$\$ 500-999$ & 23.2 & 25.8 & -2.6 & 23.8 & 21.1 & 2.7 \\
\hline $1,000-1,499$ & 10.2 & 9.5 & 0.7 & 7.9 & 9.0 & -1.1 \\
\hline $1,500-1,999$ & 4.6 & 4.2 & 0.4 & 2.6 & 3.5 & -0.9 \\
\hline $2,000-2,499$ & 2.5 & 2.2 & 0.3 & 2.4 & 2.0 & 0.4 \\
\hline $2,500-2,999$ & 1.4 & 0.6 & 0.8 & 1.3 & 0.7 & 0.6 \\
\hline $3,000-3,499$ & 0.3 & 0.5 & -0.2 & 1.7 & $0: 7$ & 1.0 \\
\hline $3,500-3,999$ & 0.3 & 0.3 & 0 & 0 & 0.4 & -0.4 \\
\hline $4,000-4,499$ & 0.5 & 0.1 & 0.4 & 0.3 & 0.3 & 0 \\
\hline $4,500-4,999$ & 0.1 & 0.2 & -0.1 & 0.3 & 0.3 & 0 \\
\hline 5,000 and over & 3.0 & 1.7 & 1.3 & 3.6 & 2.5 & 1.1 \\
\hline
\end{tabular}

'Original minus recheck. 
MEDIANS

The results of the re-enumerative check indicate that the census medians for income from self-employment may have been overstated by about $\$ 150$. The census medians for income from all other sources may have been very slightly overstated. In the case of wages and salaries, there appears to have been a sex difference, with the original median for males being lower than the recheck median by about $\$ 80$; while for females the original median is about $\$ 70$ higher.

\section{INCOME RECIPIENTS}

Perhaps the most striking finding of the PES is that the deficiency of income recipients reported in the census was caused primarily by the failure to record income from sources other than earnings. In the case of wages and salaries and of income from self-employment, the evidence from the sample indicates that the understatement of the proportions of income recipients in the census may have been quite small.

In the case of income from sources other than earnings, however, Table 20 shows that the "original" proportion of male income recipients was understated by 9.5 percentage points, and of females by 6.7 percentage points. The additional recipients are concentrated in the low-income classes. This accounts for the PES median being lower than the census median by about $\$ 150$.

\section{DISTRIBUTIONS}

Except for the consistent evidence of understatement in the census of the proportions of persons in the lowest income class ( $\$ 1$ to $\$ 500$ or loss) for each type of income, there are no clearly discernible patterns in the results.

\section{Discussion of Results}

Despite our intentions, we have "interpreted" some of the estimates of error from the standpoint of the consumer. We have labeled some of the errors as "small." But, then, this was primarily an attempt to obtain information. Are there, for example, any essential uses of census income statistics that require the medians to be accurate within $\$ 100$ ?

\section{PROBING QUESTIONS}

The re-enumerative check uncovered additional recipients of income from sources other than earnings. The PES also found more 
recipients of wages and salaries than had been identified in the 1950 census. It is conceivable that even more intensive probing might have uncovered larger numbers of recipients of very small amounts of income. Yet, if techniques intensive enough to uncover very small amounts of income had been used in the census, would the statistics have been more useful? Median incomes were based on distributions for persons who received $\$ 1$ or more of income in 1949. Would it be more desirable to base the medians on distributions beginning with $\$ 100$ or $\$ 500$ ?

\section{SELF-EMPLOYMENT INCOME}

The assumption that individual true values exist is subject to the strongest reservation in the case of income from self-employment. That the PES results are so similar to those of the census attests, however, to the statistical stability of the concept of selfemployment income.

It is of interest that the "better" method produced somewhat lower medians in the case of self-employment income. The fairly general belief that the best survey procedure "gets the most income" must be discounted if we are willing to regard a procedure that precedes a question on net income with one on gross income as "better."

\section{FUTURE CENSUSES}

Our rough-and-ready evaluation of the costs and gains suggests that there would be little to be gained by including the PEs types-ofincome inquiry in a census. The cost would be prohibitive; the improvements in accuracy, marginal. Although the PES does not provide any substantial proof, there may, however, be some merit in obtaining family income data after first determining the income of each family member separately. This plus a single question designed to uncover small amounts of income from sources other than earnings would be the most we would recommend.

\section{AGGREGATES AND AVERAGES}

The effect on the percentage distributions of income caused by underenumeration in the 1950 census was probably trivial. The same can be said for the failure on the part of the PES to find all the people that were missed in the census.

Table 3 indicates that, according to the PES, persons fourteen years old and over were understated by 1.5 per cent in the 1950 census. There is little doubt that this estimate is too low; there is some evidence that the undercount may be 3 per cent. ${ }^{6}$

'Ansley J. Coale, "The Population of the United States in 1950 Classified by 


\section{950 CENSUSA N D P E S}

We conjecture that it is even disproportionately lower in the low-income classes. This is based on the belief that the PES had the greatest difficulty in finding young adult migrants who were missed in the census, persons typically at the low end of the occupational scale.

The chief impact of underenumeration would arise in estimating family income where an independently determined income aggregate is applied to a census population total. This type of average, if not corrected for underenumeration, would be too high. Averages (and aggregates) based entirely on the 1950 census are, however, probably not seriously affected by underenumeration.

\section{SHOULD ERRORS BE MEASURED?}

The measurement of errors in statistics is a costly business. Suppose techniques of measurement of error were advanced to the point of unquestioned validity. Which would be preferable, measurements of error or more statistics?

\section{Appendix: Procedures of the Re-enumerative Check}

The study of income was but a small part of the re-enumerative check phase of the PES. The design of the check represented a compromise to achieve an optimum balance of effort over various subject matter areas.

Two overlapping probability samples were drawn, designed on the one hand to represent the land area of the United States and on the other hand to represent the persons, dwelling units, and farms enumerated in the 1950 censuses.

About 250 specially selected and trained enumerators were employed to canvass the sample of areas intensively in a search for persons, dwelling units, and farms which might have been missed in the original enumeration. These enumerators also conducted probing interviews designed to study the accuracy of the information obtained originally. In addition, these interviews were designed to uncover cases of overenumeration, that is, units listed on the rolls of the censuses that should not have been listed.

This work was carried out under close supervision; the questionnaires obtained were carefully edited both in the field and in Washington. Intensive searches were made of the census schedules before a unit was finally classified as erroneously omitted from or erroneously included in the census. Tabulations were made for selected characteristics of persons, dwelling units, and farms. These tabula-

Age, Sex, and Color-A Revision of Census Figures," Journal of the American Statistical Association, March 1955, pp. 16-54. 
tions exhibit, category by category, the estimated numbers of content differences and coverage errors that would have occurred had the PES been conducted on the entire universe rather than on a sample.

\section{THE SAMPLE}

The basic sample for the re-enumerative check was a stratified, multistage area sample of the United States. The first stage, consisting of 276 primary sampling units (counties or groups of counties), was drawn with probability proportionate to the population of the United States in 1940.

One of the major tasks of the PES was to discover households and farms which had been missed by census enumerators. To accomplish this, a segment sample was selected. This consisted of about 2,800 urban and about 1,000 rural small areas selected within the primary sample units. These small segments contained about six dwelling units in urban parts of the primary sampling units and about ten dwelling units and five farms in the rural parts.

To determine how many persons were missed in households which were enumerated, to study the extent of overenumeration in the censuses, and to study the content errors of the censuses, samples of households and farms were drawn from the census rolls. These made up what is termed the list sample of the PES. Techniques were devised to make the list sample overlap in urban areas as much as possible with the segment sample. In rural areas, the segment and list samples were drawn from the same primary sampling units but were independent of one another.

To aid the PES enumerators in canvassing the segments for missed dwelling units and farms, a special map or aerial photograph was prepared for each segment. In addition, for many segments, the PES enumerators were supplied either with photostats of the original census schedules or with lists of names and addresses of persons, dwelling units, and farms which were enumerated in or near the designated segments.

In preparing the list sample, an elaborate transcription procedure designated the specific persons, dwelling units, and farms in the list sample and provided transcriptions of the original census data for these units. To cut the cost of the program, subsamples of enumerated persons within dwelling units designated for the list sample were selected. One-half of the sample overlapped the census income sample. Transcriptions of the original census data were provided for 95 per cent of the dwelling units and persons in the sample and for 90 per cent of the farms that were sampled. A control 
group was set up by not supplying transcriptions for the remainder of the cases.

The combined segment and list samples yielded 11,800 cases for the personal income subsample and 5,500 cases for the family income subsample.

\section{DESIGN OF THE INTERVIEW}

Three major considerations governed the type of interview to be conducted in the PES. The first was that in the PES the respondent be the "best" (usually the person for whom the information was being collected). The procedure in the 1950 censuses permitted the enumerator to interview any responsible member of the household or even under certain conditions to substitute other persons, such as landlords or neighbors.

The second consideration was that a series of detailed questions be supplied for a given topic. It was believed that a more accurate answer would result than that from the single question approach of the 1950 censuses.

The third guiding principle was the belief that an on-the-spot reconciliation of differences in response between the original census enumeration and the PES would produce more accurate data.

To accomplish these objectives, separate questionnaires were designed for the persons, dwelling units, and farms in the sample. In addition, a "coverage questionnaire" was designed to aid the enumerators in identifying missed dwelling units, in identifying missed persons within enumerated dwelling units, in locating farms that might have been missed, and in checking on overenumeration of dwelling units.

\section{SUPERVISION AND TRAINING}

There were fourteen PES supervisors and fourteen assistant supervisors. These people were selected from among the most highly qualified members of the supervisory staff of the census field organization. In addition to the supervisors, working observers were provided from the headquarters of the Bureau of the Census, from other government agencies, and from university groups. The observers shared responsibility with the supervisors for the technical aspects of the PES and also participated in the training of the PES interviewers. The supervisors and observers were given three weeks of training, including a full week of practice enumeration.

About 250 enumerators were selected from among the most highly qualified personnel who worked on the 1950 censuses. No person was assigned to a sample area for which he had any responsibility in the original census enumeration. The PES enumera- 


\section{MATCHING AND QUALITY STUDIES}

tors were specialized; approximately 160 were selected to work in urban areas and approximately 90 were selected to cover rural areas. Both urban and rural enumerators received a week's training.

In addition, there was a field edit of the questionnaires and other documents of each enumerator as soon as they were received in the area offices. This was primarily designed to return defective work to the field for correction.

\section{PROCESSING} of:

The processing of returns was lengthy and complex. It consisted

1. An initial screening. To detect and send back to the field defective materials which had slipped through the field-edit procedure.

2. Editing, coding, and transcription. To prepare material for the record checks, to identify cases of possible coverage error for which special searching of the census returns was required, and to convert the information for punching and tabulation.

3. Searching. Detailed criteria were established for deciding whether or not a given unit of enumeration belonged in the class of "erroneous omissions" or of "erroneous inclusions." This demanded a careful search of the census returns.

4. Punching and tabulating. Three punch cards were prepared for every person and three for every family in the subsamples. The basic tabulations, made on a high-speed electronic computer, in practically every case took the form of Tables 1 and 2 .

In the family income results and the results for income by type, the frequencies in the basic tables represent cases in the sample adjusted to a self-weighting level. In the personal income results presented above, the frequencies in the basic tables are weighted to represent the population of the United States. To minimize the sampling error of the estimates, a final stage of "difference" estimating was employed in constructing Tables 1 and 2.

This technique is reflected in Table 1 . The column totals for the census income classes are the published totals. They were substituted for the totals derived from the sample. To adjust the breakdown in a column to add to the new total, the sum of the nondiagonal elements (the weighted PES estimate of error in the column) was subtracted from the census total. This gave a new diagonalcell entry (a "difference" estimate of the number of persons for whom no errors were made), which replaced the original sample estimate. After this adjustment, the row totals (the PES estimates) were obtained. 


\section{Exhibit A-1}

\section{Income Questions in the 1950 Census}

\begin{tabular}{|c|c|c|c|c|c|c|}
\hline \multicolumn{7}{|c|}{ FOR PERSONS 14 YEARS OF AGE AND OVER } \\
\hline \multicolumn{3}{|c|}{ Income recelved by this person in 1949} & \multicolumn{4}{|c|}{$\begin{array}{l}\text { It this person is a family bead (see deflinition below)- } \\
\text { Income recelved by bis resatives in this bousebnld }\end{array}$} \\
\hline \multirow[t]{2}{*}{$\begin{array}{l}\text { Last year } \\
\text { (1949), how } \\
\text { much money } \\
\text { did he earn } \\
\text { working as } \\
\text { an cmployee } \\
\text { for wages } \\
\text { or salary? } \\
\text { (Enter amount } \\
\text { betoro doduc } \\
\text { tlons for taxes, } \\
\text { eto.) }\end{array}$} & \multirow[t]{2}{*}{$\begin{array}{l}\text { Last year, } \\
\text { how much } \\
\text { money } \\
\text { did he earn } \\
\text { working } \\
\text { in his own } \\
\text { business, } \\
\text { profession- } \\
\text { al practice, } \\
\text { or farm? } \\
\text { (Enter net } \\
\text { Incomo) }\end{array}$} & $\begin{array}{l}\text { Last year, how } \\
\text { much money did } \\
\text { he receive from } \\
\text { interest, divi- } \\
\text { dends, veteran's } \\
\text { allowances, pen- } \\
\text { sions, rents, or } \\
\text { other income } \\
\text { (aside from } \\
\text { earnings)? }\end{array}$ & \multirow{2}{*}{$\begin{array}{l}\text { Iast year } \\
\text { (1949), how } \\
\text { much mones, } \\
\text { did his rela- } \\
\text { tires in } \\
\text { this house- } \\
\text { hold earn } \\
\text { working for } \\
\text { wages or } \\
\text { galary? } \\
\text { (Amount } \\
\text { before deduc. } \\
\text { tons for tares, } \\
\text { etc.) }\end{array}$} & \multirow{2}{*}{$\begin{array}{l}\text { Last year, } \\
\text { how much } \\
\text { money did } \\
\text { his rela- } \\
\text { tivegin } \\
\text { this house-1 } \\
\text { hold earn } \\
\text { In own } \\
\text { buslness, } \\
\text { profession- } \\
\text { al practice, } \\
\text { or farm? } \\
\text { (N I I come) }\end{array}$} & \multicolumn{2}{|c|}{$\begin{array}{l}\text { Last year, low } \\
\text { much money did } \\
\text { his relatives in } \\
\text { this household } \\
\text { receive from in- } \\
\text { terest, dividends, } \\
\text { veteran's allow- } \\
\text { ances, pensions, } \\
\text { rents, or other } \\
\text { income (aside }\end{array}$} \\
\hline & & & & & & \\
\hline & 510 & Ded & & & $0<0$ & \\
\hline
\end{tabular}




\section{Exhibit A-2}

\section{Income Questions in the PES}

29. Lat year (1849) did you do an work at all, oven for a weet or teo?

$\square$ Yoe - Plll out the Table beloe

[ 100 - stip io reen so.

TAGLE II

(1) Redeat the questione until Job hietory for entire calendar ynar. 1849. Is cospleted. It he held wore than one job during the perlod. use separato coluan for each perlod of eork and each period of dolng soaethine else.

(2) If "horklng": When uld you twe th to work?

If "Bomething el se": when did you leave your last job or bun iness before that?

(3) If "workinc": When did this work end? If "Bocetbing el se": Yoo were not corming I rom........
to when?

Dececter 31, 1949

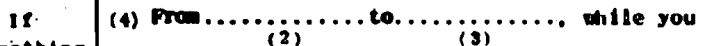

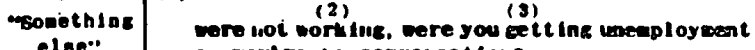

else" or wortman' cowperastion?

(5) For wow were you worklas?

LaAt Decenter (1949) wat were you

dolng -

1] Gorklag or

sociething else?

\begin{tabular}{|c|c|c|c|}
\hline \multirow[t]{2}{*}{ If } & \multirow{2}{*}{\multicolumn{2}{|c|}{ (5) For wow were you work Ing? }} & Nave of enployer \\
\hline & & & $\left.\begin{array}{l}\square \text { own tare } \\
\square \text { oon busloess }\end{array}\right\}$ saip to tee (1) \\
\hline \multirow{8}{*}{$\begin{array}{l}\text { If } \\
\text { worting } \\
\text { for } \\
\text { Someone } \\
\text { Bleo }\end{array}$} & \multicolumn{2}{|c|}{ 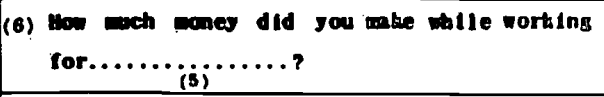 } & $\square$ Don't know astp to sten (o). \\
\hline & \multicolumn{2}{|c|}{$\begin{array}{l}\text { (7) Io this before deduct lans for texes, ooctal } \\
\text { security, etc.? }\end{array}$} & $\begin{array}{l}\square \text { Tee } \\
\square \text { No- Correct ingure in tien (c) }\end{array}$ \\
\hline & \multirow{2}{*}{\multicolumn{2}{|c|}{ 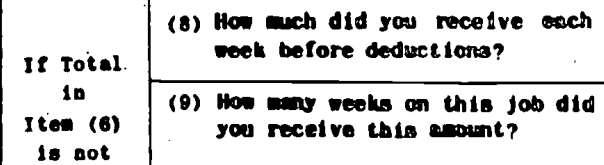 }} & \\
\hline & & & \\
\hline & troorn & $\begin{array}{l}\text { (10) Totsl asount recelved on this } \\
\text { job to } 1849-(8) \text { ties }(\theta) \text {. }\end{array}$ & 8 \\
\hline & \multicolumn{2}{|c|}{$\begin{array}{l}\text { (11) Did you recelve as tipe, bonuses, or cos- } \\
\text { Diasions from this job? }\end{array}$} & $\begin{array}{l}\square \text { res } \\
\square \text { no }\end{array}$ \\
\hline & $\begin{array}{l}\text { If } \\
\text { Itees (11) }\end{array}$ & $\begin{array}{l}\text { (13) Is this included to the } \\
\text { igi oi indi i }\end{array}$ & $\begin{array}{l}\square \text { res } \\
\square \text { Mo - correce Noure in seoe(s) or (10) }\end{array}$ \\
\hline & \multicolumn{2}{|c|}{$\begin{array}{l}\text { (13) Total waces and eselary earned in } 1949 \text { - } \\
\text { (6) or (10). }\end{array}$} & \\
\hline
\end{tabular}




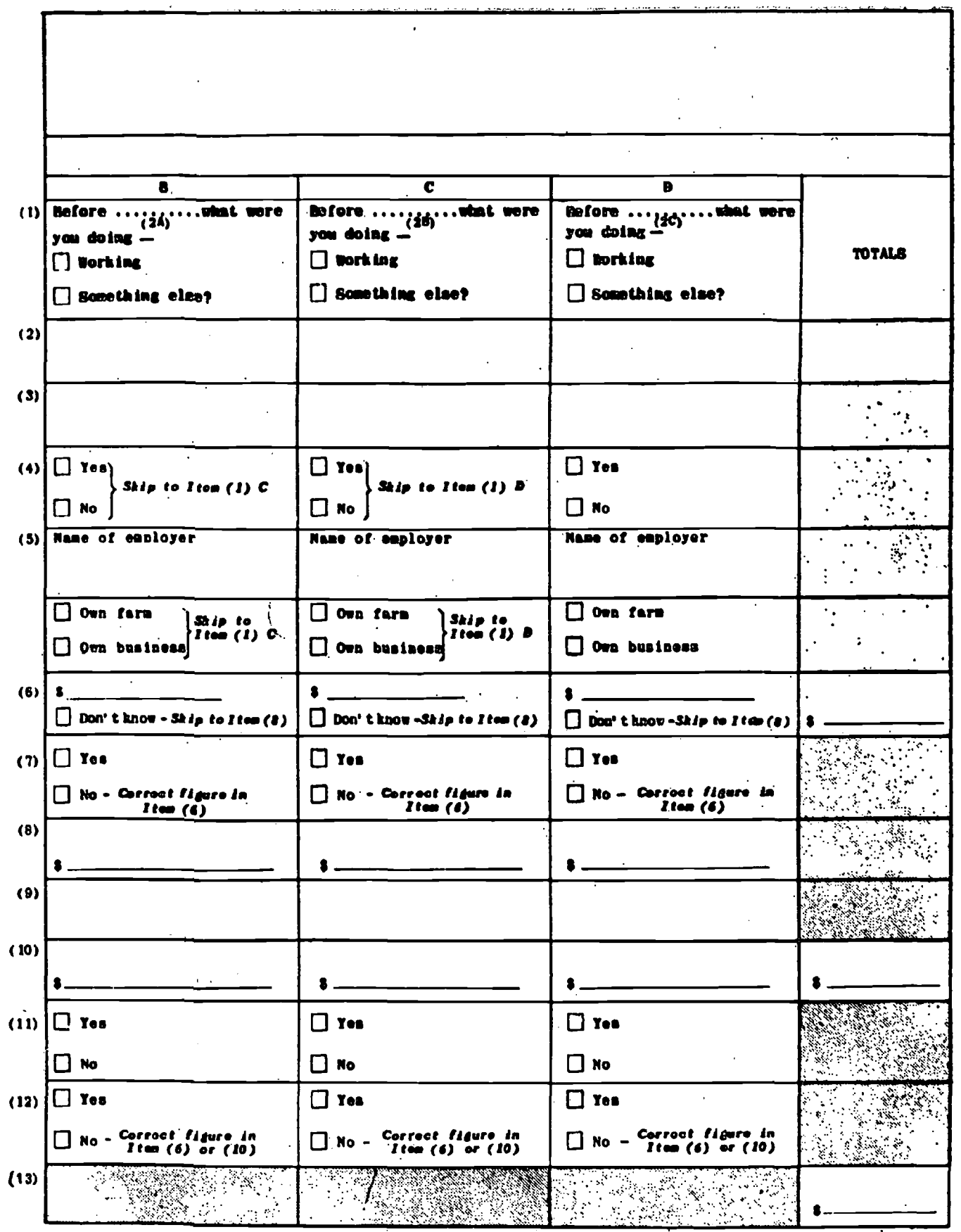




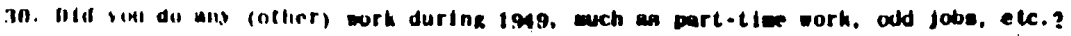

Dith - Enter inforation in Table It

No

If SBL. - EMPLOYHD AT NYY TIME DUKING 1949 NSWER ITEMB 31-33

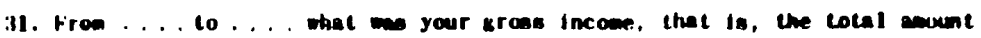
you tuxh in during that period (1t farm, Include coverneent loans on crups)?

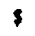

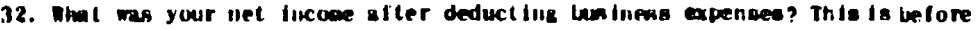
defuctiog permonal expenaes, peraonal finceme taxps, and before deductine woney opent for capital thens such as land and Iutldings, cquiparent, ma-. chinery (tractom. I rucke, etc.)?

8

3. If nonfere enf-enployeent:

a. Id you take out a calary or ake anj olher cash oflindrable from your ber Inese dur inc 1949 ?

$\square$ No

Ores

- 11 "Tes": Does the net incowe flcure of......... belude all the

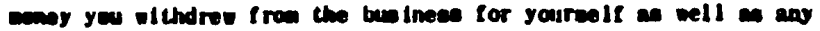
olher profits wich the besineas awle?

$\square$ No - corsect Heure In Itea s

$\square$ res 
14. Iast year, during 1949, did you recelve eny euncy irow other surcen auch as:

a. Ineploywent or vorkeen' a compenation flnclude

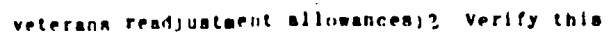
by referring lo 1 ea $z-(4)$ in table 11 .

b. Soclal securlty benel tis and governoent pentions or ansistance?

No $\square$ res 8

c. Auy other penstons or a l lounces?

$\square$ No $\square$ res 8

A. Veterens' paysents, nuch as education ans training subsigtence allowares, Innumes or di sabl 11 ty pensions?

No $\square$ res 8

e. Dependency allotments (frov weabers of the Armed Forces)?

$\square$ No $\square$ Yes 8

f. Interest, rash dividends, and income from estates and trusta?

$\square$ No $\square$ Yes

c. Becelpla froe roosers and hourders fot Incone efter expensea)?

Do $\square$ roe $\$$

h. Dente and rovaltie tron progerty

(pet lacove after experees)?

DNo $\square$ ree

1. Woney tor espopt fro parsers not living to this howehold (includine alieony)?

पn $\square$ ren

NoT: It amounte fros eny source are reported in this question or in quention 35 by are then one neaber of the fenily. ake cure these anounta are not duplicated.

35. a. Inet gear did you recelve eny wonoy fros ens other eource?

$1 \square$ No

Ores

b. If Mos. I Iat the types end cources of Incone and bho the wount

(1)

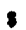

(2) s

38. Coepute the totel "other" Incone for thlo persou by addine all counts in Itere 34 and 35. 
